\title{
A rare presentation of Graves' disease: bilateral pitting edema of the legs
}

\section{Graves hastalığının nadir bir prezentasyonu: bilateral gode bırakan bacak ödemi}

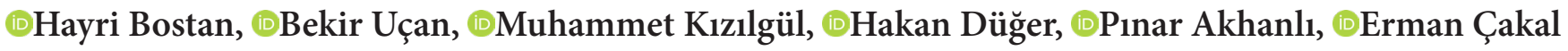 \\ Sağlık Bilimleri Üniversitesi, Dışkapı Yıldırım Beyazıt Eğitim ve Araştırma Hastanesi, Endokrinoloji ve Metabolizma Hastalıkları Kliniği, \\ Ankara, Türkiye
}

Cite this article as / Bu makaleye atıf için: Bostan H, Uçan B, Kızllgül M, Düğer H, Akhanlı P, Çakal E. A rare presentation of Graves' disease: Bilateral pitting edema of the legs. J Med Palliat Care 2021; 2(3): 95-97.

\begin{abstract}
Graves' disease has many extrathyroidal manifestations. In the literature, bilateral pretibial pitting edema in hyperthyroidism cases has been reported in a few case reports. In the current presentation, we report a case of Graves who had leg and hand swelling for two weeks and whose findings regressed rapidly with treatment. Diffuse, bilateral pitting pretibial edema, which may occur due to many etiologies, should also be considered in the differential diagnosis of hyperthyroidism.
\end{abstract}

Keywords: Graves' disease, hyperthyroidism, edema

\section{Öz}

Graves hastalığının birçok ekstratiroidal manifestasyonu bulunmaktadır. Literatürde hipertiroidizm vakalarında bilateral gode bırakan pretibial ödem az sayıdaki olgu sunumlarında bildirilmiştir. Bu sunumda, henüz iki haftadır el ve bacak şişlikleri olan ve tedavi ile hızla bulguları gerileyen bir Graves olgusunu sunduk. Birçok etyolojiye bağlı olarak ortaya çıkabilen diffüz, gode bırakan pretibial ödem hipertiroidizm ayırıcı tanısında da göz önünde bulundurmalıdır.

Anahtar Kelimeler: Graves hastalığı, hipertiroidizm, ödem

\section{INTRODUCTION}

Graves' disease, is an autoimmune disease of the thyroid gland, is characterized by hyperthyroidism, goiter, orbitopathy, and/or dermopathy. Pretibial dermopathy is rarely seen as an extrathyroidal manifestation. Pretibial myxedema due to Graves' disease is usually characterized by bilateral, asymmetrical, non-pitting, well-demarcated papules, or nodules that cause a color change and induration on the skin $(1,2)$. Orbitopathy is accompanied by dermopathy in $97 \%$ of patients (2).

While systemic edema can be seen in cases of hypothyroidism and Cushing's syndrome, it is not common in cases of hyperthyroidism (3-5). However, if the patient develops cardiac failure or pulmonary hypertension, peripheral edema may occur (6). Pitting leg edema not accompanied by cardiac failure has been reported in only a few case reports, and is a rare manifestation of hyperthyroidism (7-11).

Here, we presented a 35-year old female patient who was presented to our clinic with the complaint of swelling in the hands and legs ongoing for two weeks and was then diagnosed with Graves' disease.

\section{CASE}

A 35-year old female with no chronic disease presented at our outpatient clinic with swelling of the hands and legs and excessive sweating for the last two weeks. The patient was not taking any medication. In the family history, her 
mother had a diagnosis of autoimmune hypothyroidism. The patient was an active smoker with 10 packs/year smoking history. She described painless swelling in both hands and ankles, decreasing especially from morning to evening which had started two weeks ago. She lost three $\mathrm{kg}$ of weight in the last two weeks. She also described intermittent palpitation and mild to moderate sweating. On physical examination, the skin was slightly moist, the temperature was $36.7^{\circ} \mathrm{C}$, pulse was 86 beats $/ \mathrm{min}$, and blood pressure was $100 / 70 \mathrm{mmHg}$. On examination of the head and neck, the borders of the thyroid gland were found to be smooth and its volume was increased slightly, and there was no sensitivity on palpation. There was no evidence of thyroid ophthalmopathy. The heart sounds were rhythmic, $\mathrm{S} 1+, \mathrm{S} 2+$, and no murmur or a $3^{\text {rd }}$ sound was heard. The lung examination was normal. The liver and spleen were not palpable. Diffuse pitting edema was observed on the legs with palpation in both ankles and pretibial areas, with no accompanying color change, induration, or tenderness (Figure 1).

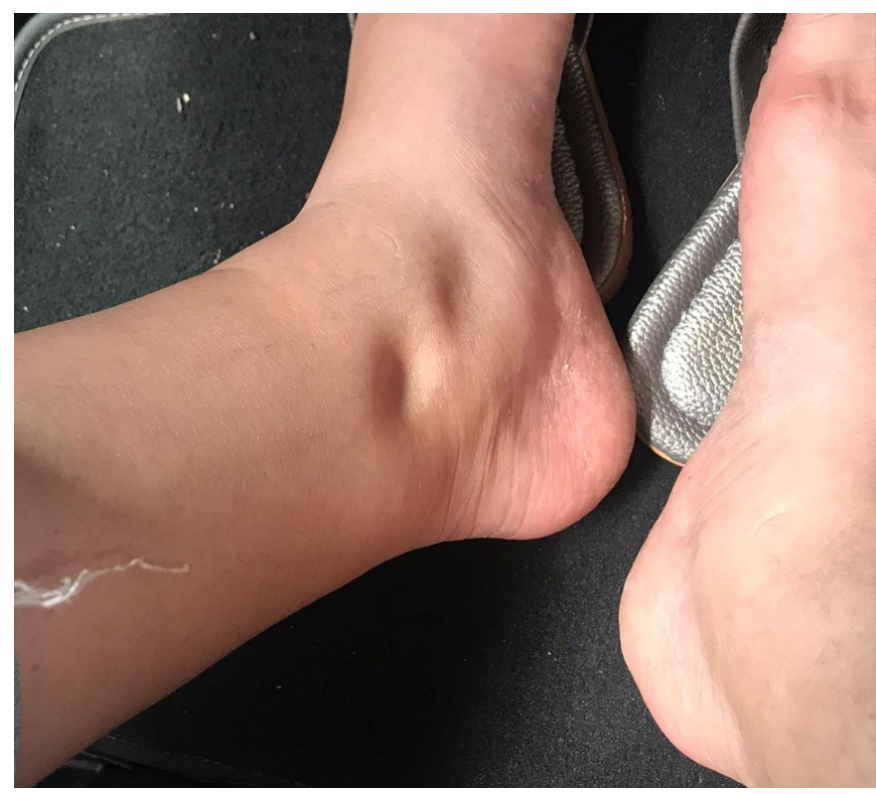

Figure 1. Sign of pitting ankle edema in the case.

In the biochemical examinations, suppressed TSH levels were accompanied by moderately increased free T3 and T4 levels. Renal and hepatic function tests were normal, and hypoalbuminemia was not detected (Table 1). No cardiomegaly or pulmonary congestion was detected on a chest X-ray. Echocardiography revealed left ventricular ejection fraction as $60 \%$. On the thyroid ultrasonography, both right and left thyroid lobe volumes were slightly increased (right: $10.5 \mathrm{~cm}^{3}$, left: $12.5 \mathrm{~cm}^{3}$ ) and diffuse millimetric hypoechoic areas were observed in the advanced heterogeneous parenchyma. On the color flow Doppler, increased thyroid blood flow was detected as Grade 2. In further assessments, increased TSH receptor antibody and other thyroid autoantibodies were detected (Table 1). Thyroid scintigraphy revealed diffuse hyperplastic thyroid gland with increased activity. Thus, the patient was diagnosed with Graves' disease and methimazole $20 \mathrm{mg} / \mathrm{day}$, and propranolol $40 \mathrm{mg} /$ day treatment was started. The swelling in the legs began to improve within three days and completely regressed about one week after the onset of treatment and did not recur. After two weeks of treatment, the free T3 and T4 levels normalized and the symptoms of thyrotoxicosis regressed.

\section{Table 1. Biochemical parameters of the patient at the time of}

\begin{tabular}{|lcc|}
\hline & Patient & Reference range \\
\hline TSH & 0.001 & $0.27-4.2 \mathrm{mIU} / \mathrm{L}$ \\
Free T4 & 3.46 & $0.93-1.7 \mathrm{ng} / \mathrm{dL}$ \\
Free T3 & 16.3 & $2-4.4 \mathrm{ng} / \mathrm{dL}$ \\
Anti-TPO & 268 & $0-34 \mathrm{IU} / \mathrm{mL}$ \\
Anti-Tg & 417 & $0-115 \mathrm{IU} / \mathrm{mL}$ \\
TRAb & 16.3 & $<0.55 \mathrm{U} / \mathrm{L}$ \\
Creatinin & 0.41 & $0.7-1.2 \mathrm{mg} / \mathrm{dL}$ \\
AST & 22 & $0-40 \mathrm{U} / \mathrm{L}$ \\
ALT & 32 & $0-41 \mathrm{U} / \mathrm{L}$ \\
Total protein & 6.49 & $6.2-8.3 \mathrm{~g} / \mathrm{dL}$ \\
Albumin & 4.11 & $3.4-5.4 \mathrm{~g} / \mathrm{dL}$ \\
Sedimentation & 12 & $0-20 \mathrm{~mm} / \mathrm{hour}$ \\
CRP & 1.04 & $0-5 \mathrm{mg} / \mathrm{L}$ \\
\hline TSH: Thyroid stimulating hormone; Anti-TPO: Thyroid peroxidase antibody; \\
Anti-Tg: Thyroglobulin antibody; TRAb: Thyroid receptor antibody; AST: Aspartate \\
aminotranferase; ALT: Alanine aminotransferase; CRP: C-reactive protein
\end{tabular}

\section{DISCUSSION}

This case presentation demonstrated a rare presentation of Graves' disease, in a patient with swelling in both the hands and legs. In this case, where cardiac, renal, hepatic etiologies were excluded and hypoproteinemia was not detected, edema began to resolve within three days of starting the appropriate treatment.

Graves' dermopathy is characterized by papular-nodular lesions, frequently bilateral, with a color change in the pretibial region, and non-pitting $(1,2)$. Nevertheless, in this case, there was bilateral diffuse pitting edema with no discoloration, induration, or tenderness in the affected area, and the findings rapidly regressed with treatment, which was contrary to classic Graves' dermopathy findings. In addition, although Graves' dermopathy is often accompanied by orbitopathy, there was no evidence of orbitopathy in this case, and it was considered that the bilateral hand and leg edema might be a different entity than dermopathy (2).

In hyperthyroidism cases, peripheral edema may develop due to congestive heart failure, pulmonary hypertension, and/or right heart failure. While left heart failure may develop in the early stages of hyperthyroidism, congestive heart failure and pulmonary hypertension may develop in the later stages (6). No evidence of left heart failure was found in the current case. 
A few cases of hyperthyroidism with bilateral pitting leg edema have been previously reported in the literature. In a patient with bilateral leg edema and diagnosed as thyrotoxicosis due to silent thyroiditis, the symptoms regressed with angiotensin receptor blocker therapy (9). Volke et al. (10) reported that a patient with unilateral leg edema had been previously diagnosed with Graves' disease. In another case, bilateral leg edema was reported in a pharmacologically-induced case of hyperthyroidism (11). In these case reports, peripheral edema was observed to develop approximately four months after the onset of thyrotoxic symptoms, but in the current case, edema developed simultaneously with thyrotoxic symptoms in a short period of two weeks. Moreover, these data show that this rare manifestation is more likely to occur in any case of hyperthyroidism rather than as a specific manifestation of Graves' disease.

A study by Kukolnikova et al. (12) showed that hyperthyroidism is one of the most common etiologies in secondary lymphedema patients. This study shows that edema in hyperthyroidism patients may be caused by impaired peripheral lymph drainage. In addition, increased thyroid hormone levels due to thyrotoxicosis/ hyperthyroidism activate various vascular mechanisms, which appear to have a role in the pathophysiology, however, the exact pathophysiological mechanism of this manifestation remains unclear.

In clinical practice, Graves' disease and other causes of hyperthyroidism should be kept in mind in the differential diagnosis of patients presenting with peripheral edema. In rare cases, this manifestation may appear as the first symptom in the early stages of the disease, before the symptoms of thyrotoxicosis are fully established.

\section{CONCLUSION}

Bilateral pitting pretibial edema is not expected in the early stages of hyperthyroidism unless there is a cardiac or pulmonary cause. We reported a rare case of Graves' disease presented with pitting leg edema. Although pitting pretibial edema is rare, it might be the first symptom in patients with Graves' disease and physicians should keep hyperthyroidism in mind in the differential diagnosis of peripheral edema.

\section{ETHICAL DECLARATIONS}

Informed Consent: Written informed consent was obtained from all participants who participated in this study.

Referee Evaluation Process: Externally peer-reviewed.

Conflict of Interest Statement: The authors have no conflicts of interest to declare.
Financial Disclosure: The authors declared that this study has received no financial support.

Author Contributions: All of the authors declare that they have all participated in the design, execution, and analysis of the paper, and that they have approved the final version.

\section{REFERENCES}

1. Ai J, Leonhardt JM, Heymann WR. Autoimmune thyroid diseases: etiology, pathogenesis, and dermatologic manifestations. J Am Acad Dermatol 2003; 48: 641-59.

2. Schwartz KM, Fatourechi V, Ahmed DD, Pond GR. Dermopathy of Graves' disease (pretibial myxedema): long-term outcome. J Clin Endocrinol Metab 2002; 87: 438-46.

3. Chajek T, Romanoff H. Cushing syndrome with cyclical edema and periodic secretion of corticosteroids. Arch Intern Med 1976; 136: 441-3.

4. Mahajan SK, Machhan PC, Sood, BR, et al. Pitting edema in hypothyroidism. J Assoc Physicians India 2003; 51: 885.

5. Hataya Y, Akamizu T, Kanamoto N, Moriyama K, Shimatsu A, Nakao K. A case of subclinical hypothyroidism developing marked pleural effusions and peripheral edema with elevated vascular endothelial growth factor. Endocr J 2007; 54: 577-84.

6. Osuna PM, Udovcic M, Sharma MD. Hyperthyroidism and the Heart. Methodist Debakey c-Cardiovasc J 2017; 13: 60-3.

7. Chapman EM, Maloof F. Bizarre clinical manifestations of hyperthyroidism. N Engl J Med 1956; 254: 1-5.

8. Toft JC, Larsen S. Tendency to edema as the initial symptom of hyperthyroidism. Ugeskr Laeger 1992; 154: 90-1.

9. Kazama I, Mori Y, Baba A, Nakajima T. Pitting type of pretibial edema in a patient with silent thyroiditis successfully treated by angiotensin ii receptor blockade. Am J Case Rep 2014; 15: 111-4.

10. Volke V, Matjus S. Unilateral pitting edema of the leg as a manifestation of Graves' disease: a case report. J Med Case Rep 2012; 6: 258

11. Novella BA, Blanco FQ, Suarez CF, Garcia IP, Molden-Hauer FD. Edema as clinical manifestation of hyperthyroidism. Report of 2 cases. An Med Interna 1996; 13: 81-3.

12. Kukol'nikova EL, Lapina NV. Etiology and pathogenesis of secondary edema of the lower extremities in patients with limited pretibialnoy myxedema on the background of hyperthyroidism. Khirurgiia (Mosk) 2011; 9: 67-70. 